Original Paper

\title{
Introduksi Pemanfaatan Tumbuhan Air Laut Sebagai Bahan Alami Pemicu Pertumbuhan Rumput Laut
}

\author{
Nunik Cokrowati ${ }^{1 *}$, Nanda Diniarti ${ }^{1}$, Dewi Nur'aeni Setyowati ${ }^{1}$, Edi Sulman $^{2}$, \\ Arziahningsih ${ }^{2}$, Rinto Basuki \\ ${ }^{1}$ Program Studi Budidaya Perairan, Fakultas Pertanian, Universitas Mataram, Lombok, NTB. \\ ${ }^{2}$ Dinas Kelautan dan Perikanan Kabupaten Sumbawa Barat, Taliwang, Kabupaten Sumbawa Barat, NTB.
}

DOI: $10.29303 /$ jpmpi.v2i2.374

Sitasi: Cokrowati, N., Diniarti, N., Setyowati, D., Sulman, E., Arziahningsih, A., \& Basuki, R. (2020). Introduksi Pemanfaatan Tumbuhan Air Laut Sebagai Bahan Alami Pemicu Pertumbuhan Rumput Laut. Jurnal Pengabdian Magister Pendidikan IPA, 2(2). doi:https://doi.org/10.29303/jpmpi.v2i2.374

*Corresponding Author: Nunik Cokrowati, Program Studi Budidaya Perairan, Fakultas Pertanian, Universitas Mataram, Lombok, NTB, Indonesia; Email:

nunikcokrowati@unram.ac.id

\begin{abstract}
Tujuan kegiatan pengabdian kepada masyarakat ini adalah untuk mengintroduksi pengetahuan masyarakat mengenai tumbuhan air laut yang dapat digunakan untuk memicu pertumbuhan rumput laut. Metode penyuluhan dilakukan dengan penyampaian materi secara langsung kepada masyarakat dalam bentuk ceramah dan menunjukkan secara langsung jenis-jenis tumbuhan air laut yang dapat digunakan uuntuk meningkatkan pertumbuhan rumput laut. Materi penyuluhan yang diberikan adalah jenis tumbuhan air laut yang dapat digunakan sebagai bahan pemicu tumbuh rumput laut dan cara aplikasinya. Kegiatan penyuluhan dilakukan di Aula Kantor Kepala Desa Kertasari Kecamatan Taliwang Kabupaten Sumbawa Barat Nusa Tenggara Barat. Kegiatan praktek aplikasi ekstark tumbuhan air tersebut dilakukan langsung di lokasi budidaya rumput laut yaitu di perairan pantai Kertasari. Kegiatan ini dihadiri oleh pembudidaya rumput laut Desa Kertasari sejumlah 25 orang dan aparatur Desa serta perwakilan dari Dinas Kelautan dan Perikanan Kabupaten Sumbawa Barat. Tumbuhan air yang memiliki zat pengatur tumbuh untuk rumput laut dan dapat dijumpai di perairan Kertasari adalah Sargassum sp, Ulva dan Tubinaria. Aplikasi penggunaan tumbuhan air tersebut di ajarkan kepada masyarakat secara langsung di lokasi budidaya rumput laut yaitu di pantai Kertasari. Tumbuhan laut tersebut di jadikan ektrak kasar dengan cara ditumbuk secara manual. Ektrak tersebut di rendamkan pada bibit rumput laut yang akan di tanam. Kesimpulan kegiatan ini adalah pengetahuan jenis tumbuhan laut yang memiliki zat pengatur tumbuh untuk rumput laut dan aplikasinya telah diintroduksi ke masyarakat pembudidaya rumput laut di Kertasari.
\end{abstract}

Keywords: Pengetahuan; Rumput Laut; Aplikasi; Pembudidaya; Kertasari.

\section{Pendahuluan}

Desa Kertasari merupakan wilayah Kecamatan Taliwang Kabupaten Sumbawa Barat Nusa Tenggara Barat. Pengembangan Pertanian, Perikanan dan Kehutanan dalam arti luas diarahkan pada pertanian maju, efisien dan tangguh yang bertujuan meningkatkan pendapatan petani dan nelayan, memperluas lapangan kerja, kesempatan berusaha, penyediaan bahan baku industri dan konsumsi masyarakat serta menunjang pariwisata. Desa Kertasari memiliki potensi budidaya rumput laut mengingat memiliki wilayah perairan berupa teluk yang produktif. Mengingat permintaan pasar dunia ke Indonesia yang setiap tahunnya mencapai rata - rata 21,8\% dari kebutuhan dunia.

Komitmen Pemerintah Kabupaten Sumbawa Barat untuk menjadikan Kertasari sebagai agroindustri rumput laut. Tahapan dan kerjasama dalam pengembangan agribisnis Rumput Laut Kabupaten Sumbawa Barat yang cukup panjang yaitu sejak 2009, berujung pada peresmian pabrik di Kertasari. Pengembangan agribisnis rumput laut sudah cukup lama, diawali sejak tahun 2009. 
Jumlah petani pembudidaya rumput laut tahun 2012 sebanyak 1.086 orang atau 412 RTP dengan 23 pokdakan. Total luas areal budidaya sekitar 306,60 Ha. Total produksi sekitar 9937,88 ton basah atau sekitar 2981,30 ton rumput laut kering tahun 2012. Pada tahun 2011, pemerintah bekerja sama dengan berbagai pihak untuk merangsang berkembang industri rumput laut. Sedangkan pada Tahun 2012, industri rumput laut ditetapkan sebagai Kompetensi Inti Industri Daerah (KIID) di Kabupaten Sumbawa Barat, dengan Permen Perindustrian RI No.136/MIND/PER/12/2012. Selain itu, ditetapkan pula Kawasan Sentra dan Kawasan Pendukung Rumput Laut Kabupaten Sumbawa Barat sebagai Kawasan Minapolitan Percontohan Tahun 2012 melalui Surat Keputusan Direktur Jenderal Perikanan Budidaya Kementerian Kelautan dan Perikanan RI. Tahun 2013-2014, Pemerintah Kabupaten Sumbawa Barat menyediakan lahan dan menambah kapasitas bangunan Pabrik Industri Rumput Laut Kertasari (Sulman, 2015).

Potensi pengembangan rumput laut di perairan Desa Kertasari cukup menjanjikan, bahkan sudah dirasakan masyarakat sebagai pendobrak peningkatan ekonomi, sehingga diharapkan kepada pemerintah Kabupaten Sumbawa Barat (KSB) untuk berperan aktif dalam menjaga potensi budidaya rumput laut. Pertumbuhan rumput laut dapat dipicu dengan memberikan bahan tambahan alami dari ekstrak tumbuhan laut yang berpotensi memiliki zat pemicu tumbuh. Tumbuhan laut tersebut yang dapat di jumpai atau diperoleh dari perairan kertasari adalah Sargassum sp., Ulva, Caulerpa dan Turbinaria. Namun masyarakat setempat belum memiliki pengetahuan mengenai hal tersebut. Sehingga perlu dilakukan introduksi pengetahuan mengenai tumbuhan air yang memiliki potensi bahan pemicu tumbuh untuk rumput laut.

\section{Metode Pelaksanaan}

Tujuan pelaksanaan kegiatan pengabdian kepada masyarakat ini adalah untuk mengintroduksi pengetahuan masyarakat mengenai tumbuhan air laut yang dapat digunakan untuk memicu pertumbuhan rumput laut dan cara mengaplikasikannya.

Metode penyuluhan dilakukan dengan penyampaian materi secara langsung kepada masyarakat dalam bentuk ceramah dan demo secara langsung menunjukkan jenis-jenis tumbuhan air laut yang dapat digunakan uuntuk meningkatkan pertumbuhan rumput laut. Materi penyuluhan yang diberikan adalah jenis tumbuhan air laut yang dapat digunakan sebagai bahan pemicu tumbuh rumput laut dan cara aplikasinya.

\section{Hasil dan Pembahasan}

Kegiatan pengabdian kepada masyarakat ini dilakukan dalam bentuk kegiatan ceramah atau penyuluhan dan praktek langsung. Materi yang diberikan pada ceramah adalah jenis-jenis tumbuhan air yang memiliki kandungan zat pemicu tumbuh untuk rumput laut. Kegiatan penyuluhan dilakukan di Aula Kantor Kepala Desa Kertasari Kecamatan Taliwang Kabupaten Sumbawa Barat Nusa Tenggara Barat. Kegiatan praktek aplikasi ekstark tumbuhan air tersebut dilakukan langsung di lokasi budidaya rumput laut yaitu di perairan pantai Kertasari. Kegiatan tersebut dihadiri oleh pembudidaya rumput laut Desa Kertasari sejumlah 25 orang dan aparatur Desa serta perwakilan dari Dinas Kelautan dan Perikanan Kabupaten Sumbawa Barat.

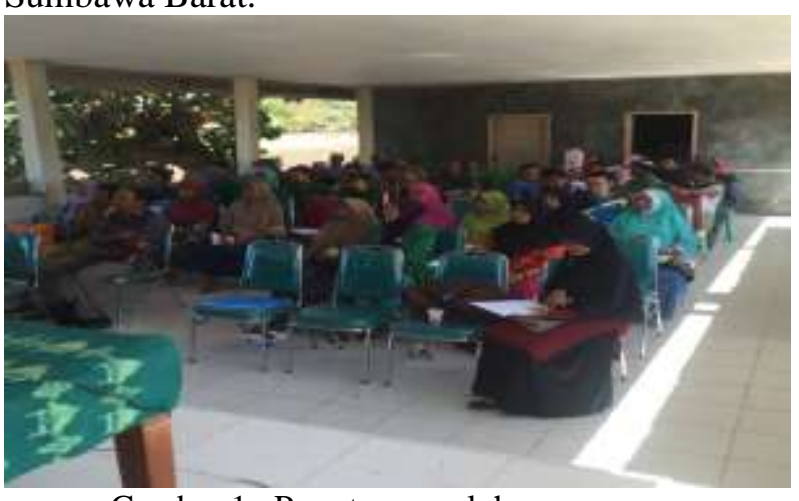

Gambar 1. Peserta penyuluhan

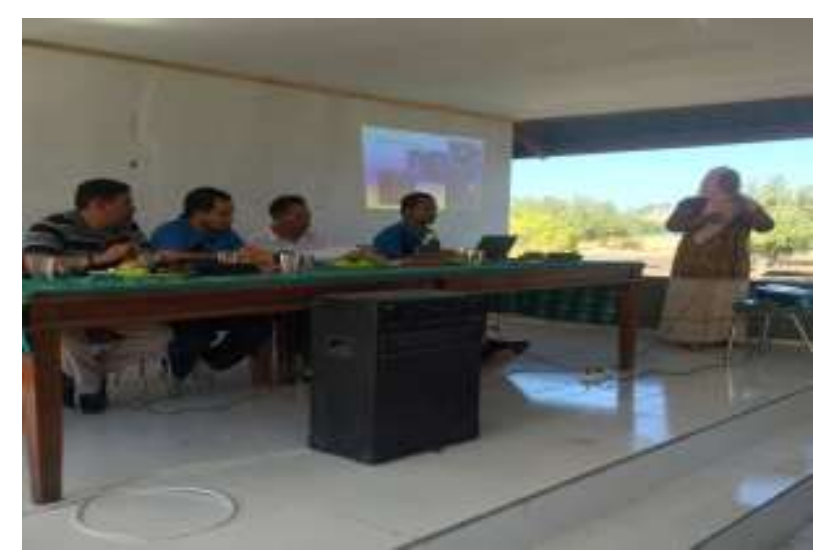

Gambar 2. Pemateri Penyuluhan 
Tumbuhan air yang memiliki zat pengatur tumbuh untuk rumput laut dan dapat dijumpai di perairan Kertasari adalah Sargassum sp, Ulva dan Tubinaria. Tumbuhan air laut tersebut tumbuh liar dan belum dimanfaatkan oleh masyarakat. tumbuhan tersebut dapat ditemukan dengan mudah di perairan Kertasari Sumbawa Barat.

Cokrowati (2017) menjelaskan bahwa Sargassum $s p$ tumbuh liar di perairan Nusa Tenggara Barat. Masyarakat awal mulanya tidak mengetahui manfaat Sargassum dan tidak tahu nilai ekonomisnya. Setelah pembeli dari Surabaya menginformasikan bahwa Sargassum dimanfaatkan sebagai bahan baku kertas minyak untuk kemasan nasi bungkus, masyarakat mulai mengambil Sargassum di perairan laut dan dijual ke pengepul. Bentuk daun melebar, lonjong atau seperti pedang. Mempunyai gelembung udara (bladder) yang umumnya soliter dan warna thallus umumnya coklat. Cokrowati, et. al., 2019 menjelaskan bahawa komponen yang ada pada Sargassum aquifolium adalah karbohidrat $(59,51 \%)$, lemak $(8,41 \%), \mathrm{Ca}(3,34 \%), \mathrm{Fe}(0,12 \%), \mathrm{P}(0,18 \%) \mathrm{Fe}$ $(0,12 \%)$, Ca $(3,34 \%)$, air $(12,79 \%)$, abu $(12,79 \%)$, $\mathrm{N}(7.22 \%)$. Komponen tersebut berpotensi sebagai fitohormon yang dapat digunakan sebagai pemicu tumbuh pada Eucheuma cottonii.

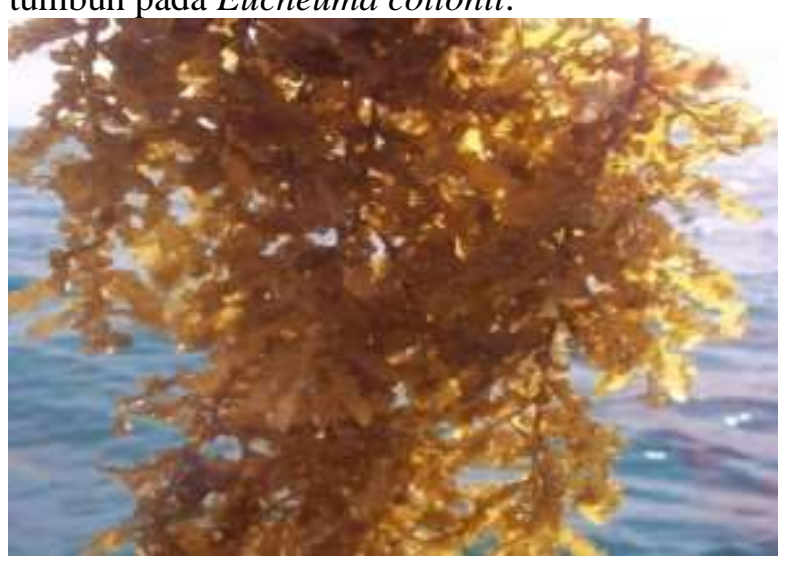

Gambar 3. Sargassum sp.

Ulva sp. adalah rumput laut yang tergolong dalam divisi Chlorophyta, karena sel-sel mengandung banyak mengandung klorofil a sehingga memberikan warna hijau pada rumput laut ini. Morfologinya berupa thallus tipis dan gepeng seperti pedang yang terdiri atas 2 lapis sel. Tidak ada diferensiasi jaringan dan seluruh sel memiliki bentuk yang kurang lebih identik, kecuali pada sel-sel basal yang mengalami elongasi membentuk rhizoid penempel. Masing-masing sel pada spesies ini terdiri atas sebuah nukleus, dengan kloroplas berbentuk cangkir, dan sebuah pirenoid (Guiry, 2007). Ulva sp. memiliki kandungan (dalam per 100 gram berat basah) : air 18,7\%, protein, $15-26 \%$, lemak $0,1-0,7 \%$, karbohidrat $46-51 \%$, serat $2-5 \%$ dan abu 16-23\%, dan juga mengandung vitamin B1, B2, B12, C, dan E (Brotowidjaya, 1984). Beckett \& Van Staden (1991) menjelaskan kandungan sitokinin pada Ulva pertusa berkisar antara 0,020,045 ppm. Sitokinin pada tumbuhan dapat meningkatkan ketahanan tanaman pada keadaan lingkungan yang buruk.

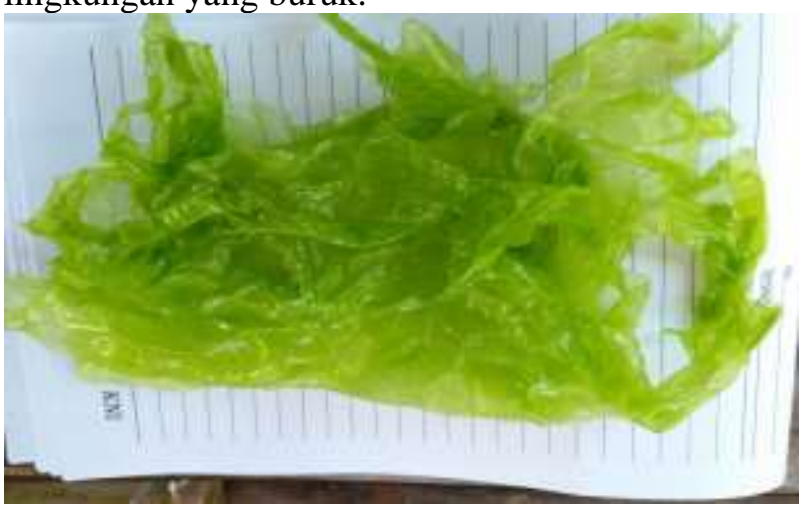

Gambar 4.Ulva sp.

Turbinaria sp. memiliki bentuk thallus silindris, tegak, kasar, terdapat bekas-bekas percabangan. Holdfast berupa cakram kecil dengan terdapat perakaran yang berekspansi radial, percabangan berputar sekeliling batang utama. Blade merupakan kesatuan yang terdiri dari tangkai dan lembaran daun umumnya berukuran kecil berdiameter berkisar $1 \mathrm{~cm}$ serta membentuk setengah bulatan melengkung seperti ginjal. Bentuk daun ada yang menyerupai kerucut segitiga dan seperti corong dengan pinggir daun bergerigi. Warna thallus coklat muda atau coklat tua dengan tinggi rumpun mencapai $75 \mathrm{~cm}$ (Wibowo et al., 2013). Sedayu (2014) yang menjelaskan bahwa Turbinaria sp. mengandung hormon pemacu tumbuh seperti, giberelin, sitokinin dan auksin yang mampu meningkatkan pertumbuhan pada tanaman. 


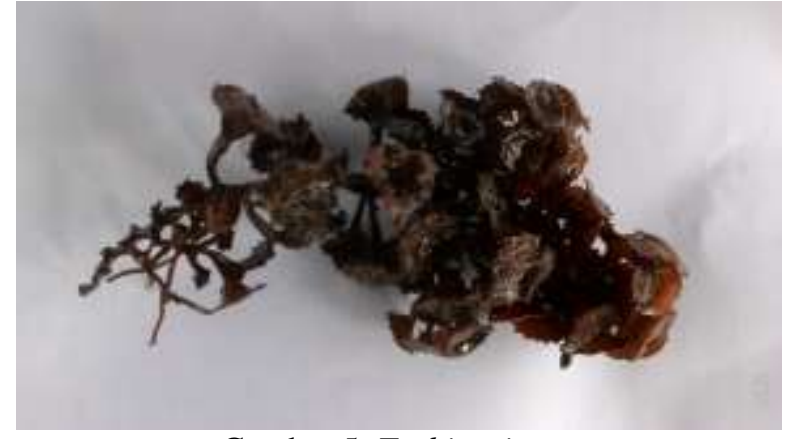

Gambar 5. Turbinaria sp.

Aplikasi penggunaan tumbuhan air tersebut di ajarkan kepada masyarakat secara langsung di lokasi budidaya rumput laut yaitu di pantai Kertasari. Tumbuhan laut tersebut di jadikan ektrak kasar dengan cara ditumbuk secatra manual. Ektrak tersebut di rendamkan pada bibit rumput laut yang akan di tanam.

\section{Kesimpulan}

Jenis tumbuhan laut yang memiliki zat pengatur tumbuh untuk rumput laut dan aplikasinya telah diintroduksi ke masyarakat pembudidaya rumput laut di Kertasari.

\section{Ucapan Terima Kasih}

Penulis mengucapkan terima kasih kepada Kementerian Riset dan Pendidikan Tinggi serta Pemerintah Kabupaten Sumbawa Barat yang telah mendukung kegiatan ini.

\section{Daftar Pustaka}

Beckett, R.P., and J.V. Staden. (1991). The effect of seaweed concentrate on the yield of salinity stress wheat. Acta Physiol. Plant. 13: 87-90.

Brotowidjaya, M.D., D. Tribuwana, dan E. Mulbyantora, 1984. Pengantar Lingkungan dan Budidaya Air. Penerbit Liberty, Yogyakarta.

Cokrowati, N. (2019). Komponen Sargassum aquifolium Sebagai Hormon Pemicu Tumbuh Untuk Eucheuma cottonii. Jurnal Biologi Tropis. Vo.19 Nomor 2 Juli - Desember 2019. Guiry, M.D. (2013). Ulva lactuca Linnaeus, 1753. Algae Base, World-wide electronic publication, National University of Ireland, Galway (taxonomic information republished from Algae Base with permission of M.D. Guiry).

Sedayu, B.B., Erawan, S. M. I., Assadad, L. (2014). Pupuk Cair Rumput Laut Eucheuma Cottonii, Sargassum sp. dan Gracilaria sp Menggunakan Proses Pengomposan. JPB Perikanan. Vol. 9 (1). 61-68 hal.

Sulman, Edi, 2015. Monografi dan Potensi Desa Labuhan Kertasari. Laporan. Dinas Kelautan dan Peternakan Kabupaten Sumbawa Barat. Taliwang Sumbawa Barat NTB.

Wibowo Y., M., Syamsul M., Anas M. F. L. A., 2011. Strategi Pengembangan Klaster Industri Rumput Laut Yang Berkelanjutan. Agritek. Fakultas Perikanan dan Ilmu Kelautan IPB. Bogor. Vol. 12 (1) : 85 - 98. 